\title{
CORPORATE SOCIAL RESPONSIBILITY REPORTING: A STUDY IN CONTEXT TO INDIA
}

\author{
Tanushree Sodhani \\ Research Scholar, Amity University UP, India \\ Dr. Alka Munjal \\ Dean (SAASS), Amity University UP, India
}

\begin{abstract}
The present study aims to focus on issues related to conducting confirmative factor analysis with selected qualitative variables of CSR reports. The target population is the services/manufacturing units of selected Indian companies. ( $n=310)$ from Maharashtra, Madhya Pradesh, Karnataka and Gujarat This study is conducted during FY2017-18 by obtaining necessary data from Government websites and other useful links. The variables that are determined for conducting factor analysis are based on sustainable report quality indicators. Factor analysis is conducted by using IBMSPSS.25 as a statistical tool. The analyzed data reflects on five hidden factors for the assessment criteria of Corporate Social Responsibility reports.
\end{abstract}

Key Words: Corporate Social Responsibility, variables, CSR reporting, hidden factors.

Cite this Article: Tanushree Sodhani and Dr Alka Munjal, Corporate Social Responsibility Reporting: A Study in Context to India, International Journal of Management, 11 (1), 2020, pp. 21-30.

http://iaeme.com/Home/issue/IJM?Volume=11\&Issue=1

\section{INTRODUCTION}

Social responsibility is the precept that agencies should add to the welfare of society and not be completely devoted to expanding advantages. This responsibility can be "poor", because of this there is an exception from fault or responsibility, or it tends to be "sure," which means that there's a duty to behave usefully. These days CSR is becoming a showcasing machine progressively throughout the board as an element of separation and mindfulness for shoppers, primarily because of the absence of item separation and the inclination of people to pick out the organization that furnishes an advanced affiliation with the clients and unique partners. The companies that grasp CSR can gather upper quit trade contenders, as an instance, firstrate open photo, awesome picture among representatives, extremely good blessings and return of the hypothesis, which is critical for assisting activities now not mainly associated with centre commercial enterprise [1], [2]. 
The phrase Corporate Social Responsibility comes across commonplace use at some stage during the $17^{\text {th }}$ century. The business mainstream is reshaped during the $20^{\text {th }}$ century with new approaches and methods in India. Ethical business philosophy should not be omitted CSR becomes critical difficulty because of the reasons like;(1) CSR allows to strengthening the association between stakeholder and company. (2) Corporate Social Responsibility also allows for constant improvement and encourages improvements (3) Corporate Social Responsibility attracts high-quality enterprise expertise as a responsible company in terms of society. (4) Corporate Social Responsibility also motivates employees to work more. (5) Corporate Social Responsibility minimizes risk due to its powerful corporation governance configuration. (6) Corporate Social Responsibility also increasing the ability to manage stakeholders` expectations and desires [3]-[5].

The Companies Act, 2013 covered more 2500 companies under CSR which have additional responsibilities to carry for the welfare of Indian society. The monetary allowance ought to touch kind of Rs. 15,000 crores. It is distinctly possible new enactment could be an awesome advantage, implanting new speculations, critical endeavours and responsibility in the manner CSR is being taken into consideration and overseen in India. It has opened new doors for all companions (counting the company phase, authorities, now not-revenue driven associations and the network everywhere) to plan creative strategies to feature to unbiased social and monetary development. At present, CSR in India is going a fine way as there as of now exists a huge number of empowering organizations and administrative bodies, as an instance, Department of Public Enterprises (DPE), Ministry of Corporate Affairs (MCA), and Indian Institute of Corporate Affairs (IICA). These groups officially got the wheels below manner which are assuming vital tasks in making CSR throughout the board exercise and in guaranteeing success in lessening disparities without playing enterprise improvement.

GRI Regional Hub South Asia, IIM Bangalore, and TCS Limited together concluded in their study report that the level of discloser via Indian corporations has long passed up indicating greater expertise of hyperlinks between sustainability practices, company overall performance and aggressive advantage. It is also observed by the authors that excessive firstrate performance facts are important to integrate sustainability throughout the enterprise. Companies that embed the records into their enterprise strategies could be capable of making more informed strategic selections. Companies and stakeholders have realized that greater transparency fosters more potent relationships which is vital for constructing long-term beliefs. CSR performance and CSR reporting are aspects of the identical coin. CSR reporting is likewise very important for corporation. At gift, CSR reporting is a worldwide popular. The present observes a problem with formal tracking and evaluation tactics of corporate social reporting. Such styles of protocols investigate nicely of CSR by means of checking excellent disclosure against pre-decided reporting factors [1], [2], [6].

\subsection{Significance of the study}

The present study is related to CSR reporting and qualitative assessment. CSR performance and quality reporting are always debatable in India. It also provides information on CSR practices to internal and external stakeholders on economic, environmental and social results achieved by an organization at a specific time duration. This study also using hidden factors for assessment criteria of CSR reports quality assessment in the Indian context. Such type of academic research is perhaps less conducted in the Indian context. The hidden factors are to be identified in this study via factor analysis. 


\section{REVIEW OF LITERATURE}

[7] Studied in their article that some of the important issues such as scientific literature, perception on quality of disclosure of social responsibility are debatable and requires concluding discussions. The authors also suggested that the researcher supplement the range of quality attributes of social responsibility disclosed. Some characteristics such as reliability and relevance, objectivity, comparability, substantiality, cleanness, accessibility and sustainability are also to be considered as informative essence by researchers. They concluded that the legal obligation of CSR data disclosure has a positive effect on the quality of the corporate social responsibility report. Heledd [8] explained that CSR is a much more communicative issue to stakeholders. They also added that the maturity of reporting by companies has variation. The authors classified CSR reporting from leaders to laggards" in the article. Their study concludes that strong leadership is necessary with strong CSR reporting to stakeholders and supporting to laggards. [9] Explained the level of CSR reporting in terms of indices, words, sentences, paragraphs, pages and other matters are given importance but it is not enough. They argued that certain information should be informed to readers and due recognition is necessary to provide relative usefulness of CSR reporting. CSR reporting can be identified in terms of the quality of the information provided by companies is necessary to be examined for the purpose of its utility. They also explained that CSR reporting machinery should sound and easy access to readers and stakeholders. Another study conducted by [10] reflects on qualitative and quantitative information on social effectiveness and the environmental effectiveness of the organization. In addition to that, a good CSR report should also reflect on the overall strategy and objectives of the company. [6] Studied that CSR report perceived as a public relations tool and not as a public document presenting actual and current situation of a socially responsible company. [11] Examined in their paper on CSR reporting that organizations' environmental and social disclosures have an important role to play in assessing CSRR. They also observed that size and revenue of company cannot be correlated with Corporate Social Responsibility and there is negative association or correlation between change in revenue as well as returns on equity, social disclosure, environmental disclose for the companies considered for research.

[12] examined in their study that information quality of disclosed in CSR reports may be grouped into two categories: The first sub-group of researchers may focus on qualitative analysis and second sub-group of researchers may focus on measuring reporting quality i.e. Quality of reports. And further studied in their article that some of the important issues such as scientific literature, perception on quality of disclosure of social responsibility are debatable and requires concluding discussions. The authors also suggested that researcher supplement the range of quality attributes of social responsibility disclosed. Some characteristics such as reliability and relevance, objectivity, comparability, substantiality, cleanness, accessibility and sustainability are also to be considered as informative essence by researchers.

Gelbmann(2010) examined in their article "Establishing Strategic CSR in SMEs: An Austrian CSR quality seal to substantiate the strategic CSR performance" that volume of report, disclosure style, topics inclusion, range of addresses of publications, nature of disclosure, manner of disclosed knowledge, period of submitted information, frequency of report and other relevant attributes are important constituent part of qualitative CSR report. [4] Examined that dimension of economic addresses that stakeholders' needs (stakeholder's means investors, suppliers, employees and customers) met efficiently and effectively. The social aspects concerned with human rights and employees' safety measures are also to be reflected in CSRR. The authors also examined that it is the duty of government to monitor public fund usage. Public funds are needed to use in a proper way and not misuse by any 
means.[13] concluded in their paper as" quality of information showed that the quality index of joint-stock index companies is higher which belong to those sectors which have a significant impact on the environment."[14] It means quality of financial and social information must be reliable and relevant. [15] Investigated that impacts of certain national, legal and organizational level factors might have differences in overall quality and coverage of other various issues in CSR reports. The authors also found that CSR environment as well as legal factor are playing important role in CSR reporting. The authors' investigation on influencing factors to CSR quality reporting such as: philanthropy and corruption [1] studied that implementation of sustainability management tools can reduce environmental impacts per unit of revenue. The authors also reported that different groups of tools are found effective for different objectives. Their observations on company size and profitability related with CSR disclosure in context to European Union.

Thus, previous literature is reviewed in relation to factors associated with this study. The key factors for the resent investigation are identified from the previous literature reviewed and they are such as: "sustainability strategy, key stakeholders, targets, trend over time, performance indicators, market place, workplace, environment, community, improvement actions, integration with business processes, executive summary, readability, basic reporting principles, data quality, stakeholders dialogue outcomes, feedback and independent verification." ( Habek \& Wolniak, 2015:231)

CSRR covers main dimensions in the present study which are: environmental, community, workplace, the market place in this study.

\section{OBJECTIVES OF THE STUDY:}

(1)To examine the quality of Corporate Social Responsibility Reporting (CSRR) with reference to CSR reporting in context to select Indian organizations. (2) To identify possible hidden factors associated with Corporate Social Responsibility Reporting (CSRR) with reference select Indian organizations. (3) To analyze hidden factors associated with Corporate Social Responsibility Reporting (CSRR) with reference select Indian organizations (4) To determine the most effective hidden factor associated with Corporate Social Responsibility Reporting (CSRR) with reference select Indian organizations.

\subsection{Hypotheses}

$\mathrm{H}_{0} 1$ : No relation exists amongst variables selected for quality assessment of CSR report in context to selected companies of India.

$\mathrm{H}_{0}$ 2: No relation exists between the quality of CSR reporting and CSR performance in context to selected companies of India.

$\mathrm{H}_{0} 3$ : No relation exists between main information of CSRR quality and additional information of CSR report in context to select companies of India.

\section{RESEARCH METHODOLOGY}

This is an analytical type of study and associated with a secondary source of data. The target population is Indian services and manufacturing companies (source www.mca.gov.in/) having CSR contribution as matching with The Companies Act,2013 related to CSR activities. Sample size is considered as 310. ( $\mathrm{N}=5097$, as CSR expenditure concern during FY2015-16). The variables determined as discussed earlier in the literature review. The $\mathrm{VAR}_{1-11}$ are categorized as relevance information and $\mathrm{VAR}_{12-17}$ are categorized as credibility of information. The complete reports on CSR expenditure point of view are selected for further analysis for the states such as Gujarat, M.P. Maharashtrians and Karnataka. Factor analysis is conducted because the main research objective is to assess the quality of information point of 
view not CSR performance. Eleven variables $\left(\mathrm{VAR}_{1-11}\right)$ related with relevant information and rest of the six-concern creditability of information. In the present study, hidden factors amongst the used variables are found. Factor analysis helps to identify the weight through loading or scree plot, KMO on importance of factors in the investigation [16]-[19]. The criterion of Kaiser-Maiser-Olkin $(\mathrm{KMO})$ coefficient takes value for a range $(<0.1>$ ) which states that bigger value between $0.7-0.9$ is considerable. (Staniz, 2007). IBMSPSS.25 is applied for data analysis for the reasons of quick and accurate output. The classification of CSR reports shown in the following manner by means of hidden factors i.e main information of report as well as additional information of the report. The following table- 1 indicates the variables considered for the purpose of analysis with their role [20], [21].

Table-1 Variables Source: Self -prepared

\begin{tabular}{|c|c|c|}
\hline VAR & Stratege sustainability & $\begin{array}{l}\text { It covers business strategy related to various dimensions of sustainable } \\
\text { development. }\end{array}$ \\
\hline $\mathrm{VAR}_{2}$ & Key Stakebolders & $\begin{array}{l}\text { It covers erganization's identification and stakebolder's expectations in a } \\
\text { way of engagement with individual groups. }\end{array}$ \\
\hline VARS & Targets & $\begin{array}{l}\text { It insooporates target set for previous, present and future inclusive of } \\
\text { reporting period and the level of achievements. }\end{array}$ \\
\hline VAR, & Tread over time & $\begin{array}{l}\text { It incorporates the signs proven over numerous reporting periods indicating } \\
\text { this way path of alemate and making sure their comparability. }\end{array}$ \\
\hline VARs & $\begin{array}{l}\text { Performance indicators ou } \\
\text { market place }\end{array}$ & $\begin{array}{l}\text { It incooporates quantitative information related to coctpany's performuance } \\
\text { achieved in market place. }\end{array}$ \\
\hline VARG & $\begin{array}{l}\text { Performance indicators: } \\
\text { work plase }\end{array}$ & $\begin{array}{l}\text { It ineoporates quantitative informatiot related to company's performanec } \\
\text { achieved in work place. }\end{array}$ \\
\hline VAR, & $\begin{array}{l}\text { Performance indicators: } \\
\text { envirounsent }\end{array}$ & $\begin{array}{l}\text { It contains quantitative informuation concerning organization's performance } \\
\text { achieved it particular area i.e. environment. }\end{array}$ \\
\hline VAR4 & $\begin{array}{l}\text { Performance indicators: } \\
\text { coemenunity }\end{array}$ & $\begin{array}{l}\text { It incorporates quantitative information about organization's performance } \\
\text { achieved in particular area i.e. commumity }\end{array}$ \\
\hline VAR & Improvenuent actioes & $\begin{array}{l}\text { It describes improvement activities vader taken by the organization to meet } \\
\text { the objectives of sustainable develograent. Programs to increase resource } \\
\text { efficiency, emission resuctioned. }\end{array}$ \\
\hline $\mathrm{VAR}_{\mathrm{H}}$ & $\begin{array}{l}\text { Integration with business } \\
\text { processes }\end{array}$ & $\begin{array}{l}\text { It incorporates information confinming that the aspects of sustainable } \\
\text { developments are included in the decisionl-making process and } \\
\text { implemented in the basic processes, purchasing. sales, marketing, and } \\
\text { prodaction less. }\end{array}$ \\
\hline $\mathrm{VAR}_{31}$ & Executive summary & $\begin{array}{l}\text { It provides a concise and balanced overview of main informatica from } \\
\text { reporting period. }\end{array}$ \\
\hline $\mathrm{VAR}_{\mathrm{B}}$ & Readability & $\begin{array}{l}\text { It has logical structure. It has also graphical representation of data and } \\
\text { explanation where required. }\end{array}$ \\
\hline VARI & Basic reporting principles & $\begin{array}{l}\text { It insorporates period of reporting, scope and entity defined including } \\
\text { limitations and target mudience }\end{array}$ \\
\hline VAR:4 & Data Qualify & $\begin{array}{l}\text { It incorporates the collection procedures, aggregation as well as data } \\
\text { trumsformation. It also determines the data source. }\end{array}$ \\
\hline VAR: & $\begin{array}{l}\text { Stakeholders dalogioe } \\
\text { outcomes }\end{array}$ & $\begin{array}{l}\text { It incorponates discussion of stakebolders dialogues and results in } \\
\text { association to aspects of stustainable developenent such as: focus group } \\
\text { enpapement, consultation survey. }\end{array}$ \\
\hline $\mathrm{VAR}_{\mathrm{it}}$ & Feedback & It incorponates mechanasm feethack processing mechamism. \\
\hline VART. & Independent venfication & $\begin{array}{l}\text { It incorporates a statement of independent body artesting the data } \\
\text { anthenticity represented in the repont and proposals for furure } \\
\text { improvements. }\end{array}$ \\
\hline
\end{tabular}

\section{DATA ANALYSIS AND INTERPRETATION}

The process of data analysis in terms of sample size $(n=310)$ and factor analysis by using IBMSPSS.25 is adopted for the parameters such as significance level $(\mathrm{p}<\mathbf{0 . 0 5}), \mathrm{KMO}$ (a measure of sample adequacy) $>0.6-<0.9$ is considered [13]. 
Table-2 KMO and Bartlett's Test

\begin{tabular}{|c|}
\hline Kaiser Meyer Olkin measure of sampling adequacy.706 \\
\hline Bartlett's Test of Sphericity Approx. Chi. square 1089.576 \\
\hline df 136 \\
\hline Sig 000 \\
\hline
\end{tabular}

Table-2 indicates the results of KMO and Barlett's test of selected 17 variables. KMO is normally standing between 0 and 1 . As a thumb of rule, $\mathrm{KMO}>0.5$, the sample is understood as adequate. In the present study, $\mathrm{KMO}=0.706$. It means variance occurs at $70.6 \%$. Such a result, factor analysis can be conducted. Here, $\mathrm{KMO}=0.706$ which indicates that the sample is aadequate and we may proceed with the Factor Analysis.

Another result on Bartlett's test of sphericity for significance level is to be considered as $95 \%$ in general. Then, $\alpha$ will be 0.05 . In this case, it is .000(Table-1) Degree of freedom (df) is related to the source of variance. The total variance has N-1. Degree of freedom, in this case, is registered as 136 .

Table-4 Total Variance Explained

\begin{tabular}{|c|c|c|c|c|c|}
\hline \multicolumn{3}{|c|}{ Initial Eigenvalues } & \multicolumn{3}{|c|}{ Extraction Sums of Squared Loadings } \\
\hline Total & \% of Variance & Cumulative \% & Total & \% of Variance & Cumulative \% \\
\hline 3.411 & 20.066 & 20.066 & 3.411 & 20.066 & 20.066 \\
1.954 & 11.496 & 31.562 & 1.954 & 11.496 & 31.562 \\
1.746 & 10.273 & 41.835 & 1.746 & 10.273 & 41.835 \\
1.367 & 8.039 & 49.875 & 1.367 & 8.039 & 49.875 \\
1.170 & 6.885 & 56.760 & 1.170 & 6.885 & 56.760 \\
.982 & 5.779 & 62.539 & & & \\
.824 & 4.846 & 67.385 & & & \\
.761 & 4.475 & 71.859 & & & \\
.738 & 4.343 & 76.202 & & & \\
.707 & 4.159 & 80.361 & & & \\
.653 & 3.841 & 84.202 & & & \\
.628 & 3.697 & 87.899 & & & \\
.511 & 3.006 & 90.905 & & & \\
.455 & 2.675 & 93.580 & & & \\
.388 & 2.282 & 95.862 & & & \\
.375 & 2.207 & 98.069 & & & \\
.328 & 1.931 & 100.000 & & & \\
\hline
\end{tabular}

Table-3 indicates that VAR 1-17 extracted. Eigenvalues are the variance of the factors. Because factors analysis has a base of the correlation matrix in the present study's analysis. Which is not shown in this paper. In this study, first five factors are retained. The variables are standardized. It means each variable has a variance of 1 . The total variance is equaled to the number of variables used in this analysis. (i.e.17)

Total column of table-4contains the eigenvalues. The first factor will always account for the most variance (and hence have the highest eigenvalue), and the next factor will account for as much of the left-over variance as it can, and so on. Hence, each successive factor will 
account for less and less variance. $\%$ of the variance contains the per cent of total variance accounted for by each factor.

Cumulative \% contains the cumulative percentage of variance accounted for by the current and all preceding factors. In this study, 5th row shows a value of 56.782. It means that the first five factors together account for $56.78 \%$ of the total variance. Table -3 indicates the results on extraction sums of squared loadings as the number of rows of the table corresponds to the number of variables retained. In this study, five factors are retained.

The following figure-1 indicates the results of the scree plot. It is .a graph of Eigenvalue against the factor number. It is observed from figure-1 that the first two columns are immediately above. Then $3^{\text {rd }}, 4^{\text {th }}$ and $5^{\text {th }}$ line have started to form but not in a flat manner. Then $6^{\text {th }}$ to $17^{\text {th }}$ have an almost flat line. It interprets that every successive factor accounting for a smaller amount of total variance.

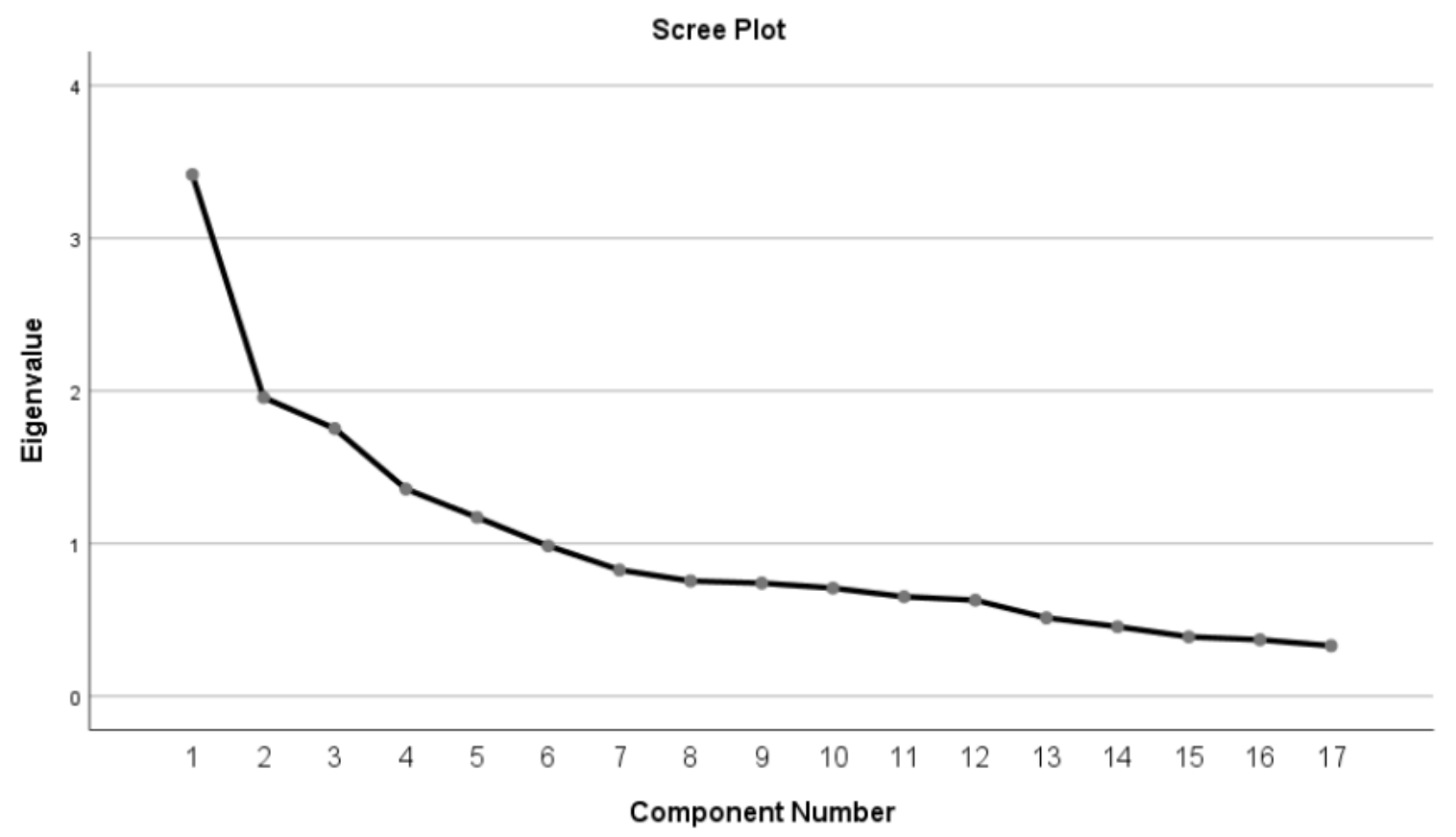

Figure-1 Scree plot

It can be interpreted that almost $70 \%$ of variables of the total variables having labelled as the main information of the report. These factors are as listed VAR $-\mathrm{VAR}_{12}$. It means: "strategic sustainability, key stakeholders, targets, and the trend over time, performance indicators (market place, workplace, environment, community, improvement actions, and integration with business processes, executive summary and readability." (Habek and Wolniak, 2016:541-547) The second identified factor accounts for 30\% of the total factors which can be identified as additional information of the reports. It includes variable related to basic reporting principles, data quality, stakeholders dialogue outcomes, feedback and independent verification. The results of 17 variables show that five $\left(\mathrm{VAR}_{13-17}\right)$ out of seventeen variables are identified as hidden factors in this study. Such five factors may be called hidden factors which are also related to the quality of CSR reporting assessment. The results on data analysis and interpretation as discussed above in this study are indicating quality assessment of CSR report in context to selected CSR reports of companies. The hypotheses of the study are tested in the study in the following manner.

$\mathrm{H}_{0} 1$ : No relations exists amongst variables selected for quality assessment of CSR report in context to selected companies of India. 
$\mathrm{H}_{1} 1$ : Significant positive relations exist amongst variables selected for quality assessment of CSR report in context to selected companies of India.

Table-2, as indicated in the study KMO, is registered at 0.706 which is more than 0.5 Moreover, significance level i.e. p-value is less than 0.05 is registered in table- 1 . It indicates that there are positive correlations amongst the variables in the study. So that, $\mathrm{H}_{0} 1$ is rejected and $\mathrm{H}_{1} \mathrm{l}$ is accepted.

$\mathrm{H}_{0} 2$ : No relations exist between quality of CSR reporting and CSR performance in context to selected companies of India.

$\mathrm{H}_{1} 2$ : Significant positive relation exists between the quality of CSR reporting and CSR performance in context to selected companies of India.

The results of this study are obtained into two different groups. One group related to the main information of CSR report and other part is additional information of the report. Both types of information are analyzed in this study and they are identified into two groups as:

$\mathrm{VAR}_{1-12}$ and $\mathrm{VAR}_{13-17}$. Such types of groups are evaluated as a result of scree plot which is a part of total variance explained in factor analysis. So that it can be said that there is a significant relationship between both the groups. That is why $\mathrm{H}_{0} 2$ is rejected and $\mathrm{H}_{1} 2$ is accepted.

$\mathrm{H}_{0} 3$ : No relations exist between the main information of CSR report and additional information of CSR report in context to selected companies of India.

$\mathrm{H}_{0} 3$ : Significant positive relation exists between main information of CSR report and additional information of CSR report in context to selected companies of India.

Table- 3 indicates the results of the total variance explained. It is also observed that the results on Rotation Sums of Squared Loadings are also suggesting interrelationship amongst VAR $_{1-17 \ldots}$ The value of commonalities (table-2) and table- 3 of the last panel of table-3 indicate the significant level in major of the cases more than 0.5. It means they have an interrelationship with each together. That is why $\mathrm{H}_{0} 3$ is rejected and $\mathrm{H}_{1} 3$ is accepted.

\section{FINDINGS}

The key results of the above-interpreted data are described as follows: (1) VAR1-17 is to some degree consistent with the CSR report's quality assessment. All variables have a special role to play in making the study more qualitative. Sustainability reports are one of the factors that affect report quality. (2) The reporting of CSR and the performance of CSR are related. Companies with higher CSR performance may be more likely to have higher readability of CSR reports. (3) Key information and supplementary report information are also found to be positively linked.

\section{LIMITATIONS OF THE STUDY}

(1) The analyses $(n=310)$ for the analysis were mostly independent CSR studies. Sometimes, however, the company includes CSR issues in its annual report and draws up a separate CSR report. But the researchers could not obtain such information. (2) There are companies which generate CSR reports regardless of the nature of the reporting requirement making it difficult to classify the report into the voluntary or mandatory category. (3) This is an academic research and has considerations such as time constraints and funding problems.

\subsection{Implications of the study to stakeholders}

The results show stakeholder involvement in the CSR process and stakeholder empowerment. Stakeholders should have the right to know about the company's social performance. CSR coverage will assist stakeholders in collecting objective information and meaningful 
accountability in ethical organizations. In short, proactive CSR reporting will make stakeholders more active in organizational CSR activities.

\section{CONCLUSION}

The identified hidden factors are unknown factors amongst the used variables. Extrapolation helped in identifying such factors in the present study. The factors analyzed for the purpose of this study have given fruitful results on CSR reporting by companies in India. It is also to be noted that CSR performance and CSR reporting in a qualitative manner are reciprocally related to each other. The most influential factor on quality assessment of CSR reporting is performance indicator as a market place. It has highest variance as one of the hidden factors $\left(\mathrm{VAR}_{5}\right)$ as shown in table-4. Thus, the present study is examined in terms of quality assessment of CSR reporting in the Indian context

\section{Further Research Opportunities and Recommendations}

The author(s) see some further research opportunities. The research could concentrate on other factors such as fundamental reporting and management awareness. It would also be interesting to study the effect on sustainable reporting patterns of global, political, education, labour and cultural systems. Such recommendations can be made based on the study conducted to identify and analyze variables for the assessment of CSR quality reporting. Indian companies must take initiatives for qualitative reporting of CSR Indian firms must initiate key information initiatives in the report rather than simply on CSR expenses. Initiatives for the relevance of CSR information should be taken by Indian companies. Indian companies need to take initiatives towards additional information relating to fundamental reporting principles, quality of data results from stakeholder dialogues, feedback and independent verification. Indian companies can prove the public report of CSR not only to the public in terms of financial performance and social services.

\section{REFERENCES}

[1] D. Haski-Leventhal and J. Concato, "The State of CSR and RME in Business Schools and the Attitudes of their Students," p. 38, 2016.

[2] P. Mirvis, "Employee Engagement and CSR: Transactional, Relational, and Developmental Approaches," Calif. Manage. Rev., vol. 54, no. 4, pp. 93-117, 2012.

[3] A. A. Albdour and I. I. Altarawneh, "Corporate Social Responsibility and Employee Engagement in Jordan,” Int. J. Bus. Manag., vol. 7, no. 16, pp. 89-105, 2012.

[4] S. M. Hart, "Self-regulation, corporate social responsibility, and the business case: Do they work in achieving workplace equality and safety?,” J. Bus. Ethics, vol. 92, no. 4, pp. 585$600,2010$.

[5] W. Te Liew, A. Adhitya, and R. Srinivasan, "Sustainability trends in the process industries: A text mining-based analysis," Comput. Ind., vol. 65, no. 3, pp. 393-400, 2014.

[6] O. V Petrenko, F. Aime, J. Ridge, and A. Hill, "Corporate social responsibility or CEO narcissism? CSR motivations and organizational performance," Strateg. Manag. J., vol. 37, no. 2, pp. 262-279, 2016.

[7] K. V Lins, H. Servaes, and A. Tamayo, "Social capital, trust, and firm performance: The value of corporate social responsibility during the financial crisis," J. Finance, vol. 72, no. 4, pp. 1785-1824, 2017.

[8] C. Kang, F. Germann, and R. Grewal, "Washing away your sins? Corporate social responsibility, corporate social irresponsibility, and firm performance," J. Mark., vol. 80, no. 2, pp. 59-79, 2016.

[9] H. Liang and L. Renneboog, "On the foundations of corporate social responsibility," J. Finance, vol. 72, no. 2, pp. 853-910, 2017.

[10] D. Jamali and C. Karam, "Corporate social responsibility in developing countries as an emerging field of study,” Int. J. Manag. Rev., vol. 20, no. 1, pp. 32-61, 2018. 
[11] Ghanasham S. Joshi, A Study of Corporate Social Responsibility Reporting In India, Journal of Management, 5(6), 2018, pp. 129-136.

[12] J. G. Frynas and C. Yamahaki, "Corporate social responsibility: Review and roadmap of theoretical perspectives," Bus. Ethics A Eur. Rev., vol. 25, no. 3, pp. 258-285, 2016.

[13] D. Jamali, C. Karam, and M. Blowfield, "Introduction: Corporate social responsibility in developing countries: a development-oriented approach," in Development-Oriented Corporate Social Responsibility: Volume 2, Routledge, 2017, pp. 1-12.

[14] C. Sutton, "The role of the financial services sector in expanding economic opportunity," Corp. Soc. Responsib., pp. 11-15, 2007.

[15] Dr. Pooja Deshmukh, Corporate Social Responsibility and Education Sector: Issues and Remedies. International Journal of Management, 8(1), 2017, pp. 137-144.

[16] M. Welch, "The evolution of the employee engagement concept: communication implications," Corp. Commun. An Int. J., vol. 16, no. 4, pp. 328-346, 2011.

[17] M. Kaliannan and S. N. Adjovu, "Effective Employee Engagement and Organizational Success: A Case Study," Procedia - Soc. Behav. Sci., vol. 172, pp. 161-168, 2015.

[18] S. Dixit, S. N. Mandal, J. V Thanikal, and K. Saurabh, "Evolution of studies in construction productivity: A systematic literature review (2006-2017)," Ain Shams Eng. J., 2019.

[19] S. Dixit, S. N. Mandal, J. V Thanikal, and K. Saurabh, "Study of Significant Factors Affecting Construction Productivity Using Relative Importance Index in Indian Construction Industry," vol. 09010, 2019.

[20] Ghanasham S. Joshi and Dr. R. L. Hyderabad, Determinants of Corporate Social Responsibility Reporting in India Management a Review. Journal of Management, 6(1), 2018, pp. 1-10.

[21] S. Dixit, "Science Direct Analyzing the Impact of Construction Productivity over Infra Projects : Indian Scenario," vol. 00, no. May, 2019.

[22] M. N. Shah, S. Dixit, R. Kumar, R. Jain, and K. Anand, "Causes of delays in slum reconstruction projects in India," Int. J. Constr. Manag., pp. 1-16, Jan. 2019.

[23] Harish G Ugraiah and Dr. M. S. Ranga Raju, Voluntary Corporate Social Responsibility (VCSR) - an Entrepreneur's Perspective (with Special Reference to Business Units in Bangalore, India). International Journal of Management, 7(6), 2016, pp. 23-36.

[24] B. Jørgensen and S. Emmitt, "Lost in transition: the transfer of lean manufacturing to construction," Eng. Constr. Archit. Manage., vol. 15, no. 4, pp. 383-398, 2008.

[25] M. I. Khan, "A Study of Marketing Strategies Part 1," Int. J. Mark. Technol., vol. 2, no. 5, pp. 231-251, 2012.

[26] Zaryab, T. Value Creation Model in Corporate Social Responsibility. International Journal of Advanced Research in Management, 6(3), 2015, pp. 18-28.

[27] Dr. Vineet Singh, Role of FMCG Companies towards Corporate Social Responsibility (Indian Insight). International Journal of Marketing and Human Resource Management, 7(1), 2016, pp. 15-20.

[28] Dr. E. Manohar, Essential Alignment: Corporate Social Responsibility and Social Impact Assessment for Sustainable Development - An Empirical Study, Journal of Management, 6 (3), 2019, pp. 186-191.

[29] Ashish Tripathi and Dr Kirti Agarwal, Corporate Social Responsibility- Impact on the Profitability \& Sales of Indian Selected Organizations, International Journal of Advanced Research in Management (IJARM), Volume 6, Issue 1, January-April (2015), pp. 60-71

[30] Pawan and Gautam J.N., Cost-benefit Analysis of Journals subscription at Nehru Library, CCSHAU, Hisar, Haryana, International Journal of Management, 10 (2), 2019, pp. 261-274.

[31] Ghanasham S. Joshi and Dr. R. L. Hyderabad, Determinants of Corporate Social Responsibility Reporting in India Management a Review. Journal of Management, 6(1), 2018, pp. $1-10$ 